\title{
Recruiting students to undergraduate geoscience programs through dual-credit and dual-enrollment classes
}

\author{
Aida A. Awad, Science Dept. Chair, Maine East High School, 2601 W. Dempster \\ Street, Park Ridge, Illinois 60068, USA; aawad@maine207east.k12.il.us \\ Stephen R. Mattox, Dept. of Geology, Grand Valley State University, Allendale, \\ Michigan 49401-9403, USA; mattoxs@gvsu.edu
}

\section{INTRODUCTION}

The GSA's Committee on Education shares the concern of numerous geoscience agencies about the looming shortage of geoscientists in the workforce. Geoscience departments are actively seeking new students to add stability and diversity to their programs. We encourage GSA members to consider supporting broader use of existing dual-enrollment and dual-credit course options. Dual-enrollment courses for high school students are taught by college faculty, commonly at the university. Dual-credit courses are taught in high school by qualified high school teachers. A majority of states allow high schools, two- and four-year colleges, and universities to offer dual-credit and/or dual-enrollment courses for academically qualified high school students. At present, such courses are most frequently offered in mathematics, chemistry, and physics. As members of the GSA Committee on Education, we believe it is time that GSA members with departments at two-year and four-year institutions should explore the possibility of dual-credit or dual-enrollment courses to better promote the geosciences.

Your institution probably already allows dual-enrollment courses in other disciplines. When in direct partnership with a school district, such courses are often conducted during regular public school hours. Other models include course offerings provided at times suitable for high school students, such as late afternoon or evening. Many of your general education courses, such as environmental or physical geology, would qualify and greatly benefit the upper-division high school student.

Allowing dual-enrollment courses in your department has numerous benefits. For example, your faculty would have an opportunity to engage talented students in geoscience before they have selected a career or even a college. At some colleges and universities, these courses are directly drawing new students to their programs. At a minimum, allowing these students in your classroom elevates public geoscience literacy.

Dual-credit courses require a well-trained high school teacher, commonly with an M.S. in geology or geoscience education, partnered with a faculty member from a two- or four-year institution.

\section{EXAMPLES}

The Oneonta Earth Sciences Outreach Program was developed by James Ebert. This program allows high school students to enroll in advanced earth-science courses at their high schools and earn college credit from the State University of

GSA Today, v. 19, no. 4/5, doi: 10.1130/GSATG43GW.1
New York (SUNY)-Oneonta. Students can apply their credits to SUNY-Oneonta or other SUNY institutions, or apply for transfer credit to another college they choose to attend. Since its inception in 2007 , the program has grown to include ten high schools from across the state. High school teachers have offered ten different courses for college credit, including "Science of Natural Disasters," "Planet Earth" (formerly "Introduction to Geology"), "Introduction to Forensic Geology," and "Water and the Blue Planet." Ebert believes that teachers' passions should determine the course content. Furthermore, he doesn't impose a standardized test as a threshold toward earning credit. Instead, he relies on the rigor reflected in the course syllabi and materials selected by the high school teachers. The grade earned by the student in these advanced high school courses is the basis for college credit.

In California, Wendy Van Norden has developed a year-long honors geology course that is accepted at the University of California-Los Angeles (UCLA). The course uses Reynold's Exploring Geology (Reynolds et al., 2008) as a text and the National Association of Geoscience Teachers lab manual. The high school grade is based on homework, labs, tests and quizzes, field trips, a winter final, and a year-end final. Each student must pass an exam prepared by Ray Ingersoll of UCLA to be eligible for the college credit. UCLA requires US\$400 to process the credit award. As part of the course requirements, Van Norden runs field trips to Death Valley and the Santa Monica Mountains and optional field trips to the Mojave Desert and Santa Paula.

In north suburban Chicago, Xiaoming Zhai of the College of Lake County developed a dual-credit four-credit hour equivalent earth-science program that is now in its second year. The course has 
flourished in large part because of the opportunity it provides students to earn college science laboratory credit in a non-traditional way. Zhai works closely with the high school faculty to ensure the rigor of the course. He strongly believes that many students participating in the program are motivated and engaged by the content and its relevance to their lives in a way they have not experienced in their previous science classes. This program is generating enthusiasm for the geosciences!

Hudsonville High School is in a small, rural Michigan town with a population of about 8,000. Ninth-grade students are required to take two trimesters of earth science, a rigorous course series that includes inquiry-based labs, providing a solid foundation in geology. The geology course for 11th- or 12th-grade students is taught by Chris Bolhuis. Students earn credit for the course by taking an exam prepared by faculty at Grand Valley State University (GVSU). The course includes two extended field trips: In the fall, students travel to the Porcupine Mountains; in the spring, they travel to Pictured Rock National Lakeshore. Bolhuis also co-teaches a summer class called Summer Science Institute. The class is a one credit-hour, three-week field course in geology and ecology in the western United States. Since 2001, 197 students have taken the exam provided by GVSU. One hundred and seventy-two students have passed the exam (an impressive 87\%, which is probably higher than the university pass rate). At least 32 students have become geology or earth-science majors.

\section{CONCLUSIONS}

Students may earn both high school and college credits during dual-credit and/ or dual-enrollment experiences. If using the high school design, the high school teacher is required to have a master's degree in geology or earth science and must work closely and collaboratively with a nearby institution of higher education. Examples include cooperation between public school systems and community colleges and universities. Whether on a high school or post-secondary campus, the courses are expected to maintain the same academic rigor as a standard college course.

GSA members probably already know of skilled earth-science teachers in their communities. What better way to promote geoscience than to support our best local teachers?

\section{REFERENCE CITED}

Reynolds, S., Johnson, J., Kelly, M., Morin, P., and Carter, C., 2008, Exploring Geology: New York, McGraw Hill, 575 p.

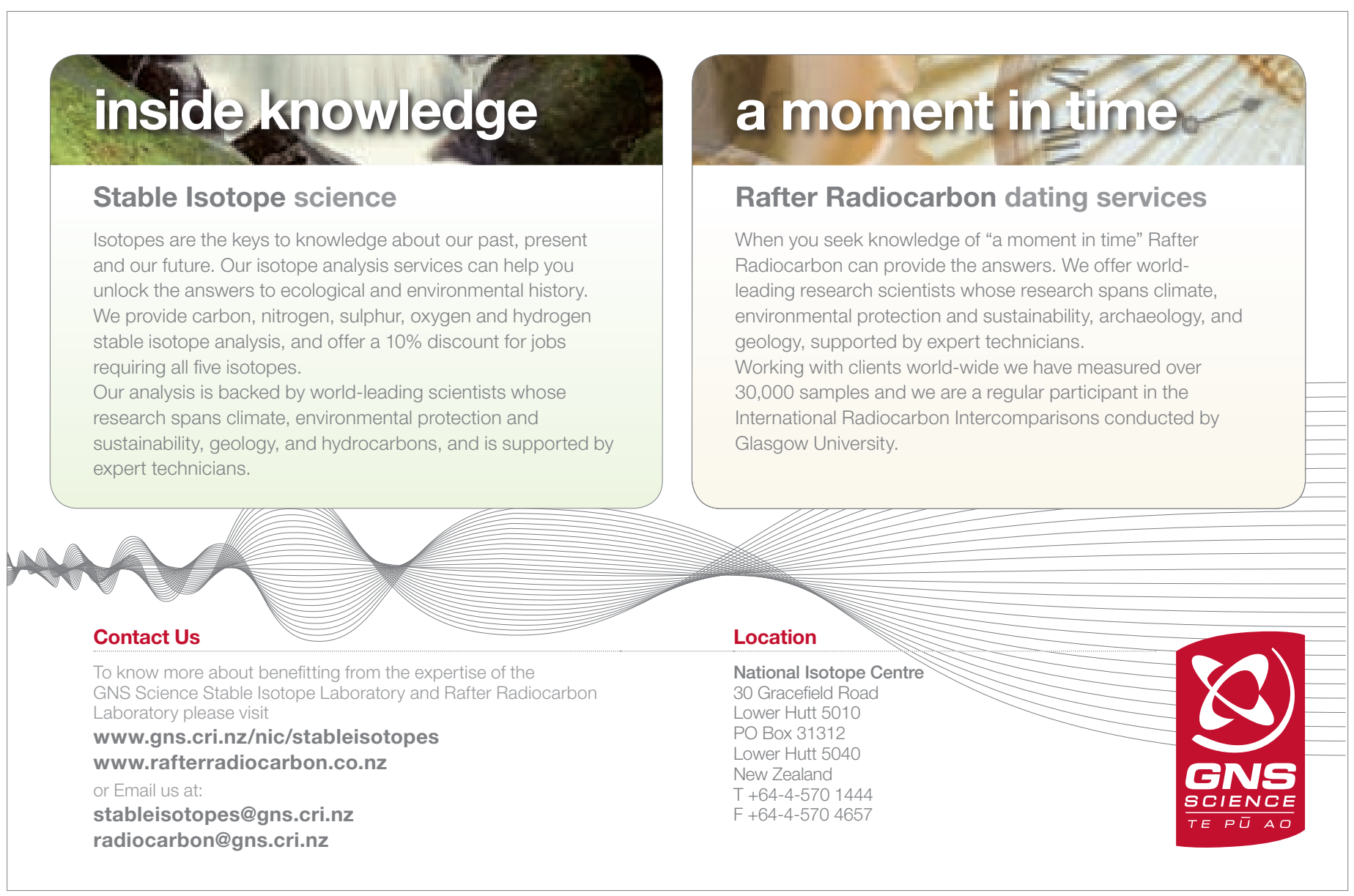

